Article

\title{
Investigation of the Thermodynamic Properties of Surface Ceria and Ceria-Zirconia Solid Solution Films Prepared by Atomic Layer Deposition on $\mathrm{Al}_{2} \mathrm{O}_{3}$
}

\author{
Tzia Ming Onn, Xinyu Mao, Chao Lin, Cong Wang and Raymond J. Gorte * \\ Department of Chemical and Biomolecular Engineering, University of Pennsylvania, 34th Street, \\ Philadelphia, PA 19104, USA; tonn@seas.upenn.edu (T.M.O.); xinyumao@seas.upenn.edu (X.M.); \\ linchao@seas.upenn.edu (C.L.); wangcong@seas.upenn.edu (C.W.) \\ * Correspondence: gorte@seas.upenn.edu
}

Received: 29 August 2017; Accepted: 11 October 2017; Published: 15 October 2017

\begin{abstract}
The properties of $20 \mathrm{wt} \% \mathrm{CeO}_{2}$ and $21 \mathrm{wt} \% \mathrm{Ce}_{0.5} \mathrm{Zr}_{0.5} \mathrm{O}_{2}$ films, deposited onto a $\gamma-\mathrm{Al}_{2} \mathrm{O}_{3}$ by Atomic Layer Deposition (ALD), were compared to bulk $\mathrm{Ce}_{0.5} \mathrm{Zr}_{0.5} \mathrm{O}_{2}$ and $\gamma-\mathrm{Al}_{2} \mathrm{O}_{3}$-supported samples on which $20 \mathrm{wt} \% \mathrm{CeO}_{2}$ or $21 \mathrm{wt} \% \mathrm{CeO}_{2}-\mathrm{ZrO}_{2}$ were deposited by impregnation. Following calcination to $1073 \mathrm{~K}$, the ALD-prepared catalysts showed much lower XRD peak intensities, implying that these samples existed as thin films, rather than larger crystallites. Following the addition of $1 \mathrm{wt} \% \mathrm{Pd}$ to each of the supports, the ALD-prepared samples exhibited much higher rates for CO oxidation due to better interfacial contact between the Pd and ceria-containing phases. The redox properties of the ALD samples and bulk $\mathrm{Ce}_{0.5} \mathrm{Zr}_{0.5} \mathrm{O}_{2}$ were measured by determining the oxidation state of the ceria as a function of the $\mathrm{H}_{2}: \mathrm{H}_{2} \mathrm{O}$ ratio using flow titration and coulometric titration. The $20 \mathrm{wt} \% \mathrm{CeO}_{2}$ ALD film exhibited similar thermodynamics to that measured previously for a sample prepared by impregnation. However, the sample with $21 \mathrm{wt} \% \mathrm{Ce}_{0.5} \mathrm{Zr}_{0.5} \mathrm{O}_{2}$ on $\gamma-\mathrm{Al}_{2} \mathrm{O}_{3}$ reduced at a much higher $P_{\mathrm{O}_{2}}$ and showed evidence for transition between the $\mathrm{Ce}_{0.5} \mathrm{Zr}_{0.5} \mathrm{O}_{2}$ and $\mathrm{Ce}_{0.5} \mathrm{Zr}_{0.5} \mathrm{O}_{1.75}$ phases.
\end{abstract}

Keywords: Atomic Layer Deposition; ceria; ceria-zirconia; thermodynamics; improved stability

\section{Introduction}

Ceria is a component in a number of commercial catalysts, as demonstrated in a recent, comprehensive review [1]. Two important examples include the use of ceria-based materials as oxidation catalysts in Diesel particulate filters [2] and the use of ceria-zirconia solid-solutions as Oxygen-Storage Capacitors (OSC) in automotive three-way catalysts [3-7]. The critical property of ceria that makes it useful in these and other catalytic applications is the relative ease with which it changes oxidation states between $\mathrm{Ce}^{3+}$ and $\mathrm{Ce}^{4+}$. This, together with the fact that reduced ceria can be oxidized by steam or $\mathrm{CO}_{2}$ [8] and then transfer oxygen to transition metals with which it is in contact make it a promoter of hydrocarbon oxidation [9,10], water-gas-shift (WGS) reaction [11-14], steam reforming [15-18], and more.

It is known that pure ceria becomes essentially unreducible after harsh redox cycling [19]. Although this loss in reducibility is accompanied by a loss in surface area, it is not simply a kinetic phenomenon, since the ceria-zirconia solid solutions that are used in three-way catalysts also have low surface areas but still maintain their OSC properties [20]. While the loss in surface area does not prevent the application of ceria-zirconia solid solutions for OSC, high surface areas are required in other cases. For example, for CO-oxidation and WGS reactions over Pd/ceria, the sites at the Pd-ceria boundary have been shown to exhibit much higher rates [21]. In these examples, the surface area of the ceria should be as high as possible. 
An obvious approach for maintaining a high surface area for the ceria phase is to deposit it onto a high-surface-area support that has good thermal stability, such as $\gamma-\mathrm{Al}_{2} \mathrm{O}_{3}$. The ceria phase is usually added by infiltration with metal salts, followed by calcination; however, the use of a support for the ceria phase is often only partially effective because the ceria does not typically cover the entire surface. For example, rates on a catalyst in which $\mathrm{Pd}$ is deposited onto a ceria $/ \gamma-\mathrm{Al}_{2} \mathrm{O}_{3}$ support prepared by infiltration of ceria are often much lower than rates on ceria-supported Pd because much of the Pd is not in contact with ceria in the former case [22]. Finally, it can be difficult to produce a supported, ceria-zirconia solid solution because this requires good mixing of the Ce and $\mathrm{Zr}$ cations during the precipitation stage in catalyst preparation.

Work from our laboratory has recently demonstrated that one can use Atomic Layer Deposition (ALD) to prepare thin ceria [22] and ceria-zirconia [23] films that uniformly cover a $\gamma-\mathrm{Al}_{2} \mathrm{O}_{3}$ support. The principle behind ALD is that an organometallic precursor is allowed to react with the substrate surface, after which the adsorbed precursor is oxidized in a separate step. Because reaction of the precursor with the substrate is limited to a monolayer at most, ALD allows the formation of uniform, atomic-scale, oxide films. There are comprehensive reviews of ALD topics that are available [24,25]. Mixed oxides are easily formed by alternating between different precursors. Because oxides have low surface energies compared to metals, the uniform films formed by ALD tend to be thermally stable. In the cases of ceria and ceria-zirconia films on $\gamma-\mathrm{Al}_{2} \mathrm{O}_{3}$, the $\gamma-\mathrm{Al}_{2} \mathrm{O}_{3}$ remains "covered", even after calcination to $1173 \mathrm{~K}$.

As mentioned previously, the reducibility of ceria depends on the surface area and/or crystallite size $[19,26]$ and ceria-zirconia solid solutions are more reducible than pure ceria $[20,27]$. Because the films prepared by ALD can be sub-nanometer in thickness, it is anticipated that the reducibility of these materials may be very different from even ordinary polycrystalline ceria. Quantification of reducibility can be difficult and kinetic measures, such as Temperature Programmed Reduction peak temperatures, can be dramatically affected by the presence of catalysts and other factors. Therefore, we chose to quantify reducibility by measuring the thermodynamic properties of ALD-prepared films using flow titration and coulometric titration $[20,27]$. In both of these techniques, the sample is equilibrated at high temperatures in a specified $P_{\mathrm{O}_{2}}$ and the extent of ceria reduction (e.g., $x$ in $\mathrm{CeO}_{(2-x)}$ ) is then determined as a function of that $P_{\mathrm{O}_{2}}$ and temperature. The $P_{\mathrm{O}_{2}}$ is typically established by equilibrium with $\mathrm{H}_{2}$ oxidation (i.e., $P_{\mathrm{O}_{2}}=K_{\text {equi }}^{-1} \frac{P_{\mathrm{H}_{2} \mathrm{O}}}{P_{\mathrm{H}_{2}}}$ ) and is therefore fixed by passing a mixture of $\mathrm{H}_{2}$ and $\mathrm{H}_{2} \mathrm{O}$ over the sample at a specified $\mathrm{H}_{2} \mathrm{O}: \mathrm{H}_{2}$ ratio. Because the activity of solids is one, the equilibrium constant for oxidation of $\mathrm{CeO}_{(2-x)}$, and therefore the free energy of oxidation at that value of $x$, is determine directly from the measured $P_{\mathrm{O}_{2}}$. Furthermore, the temperature dependence of the equilibrium constant can be used to determine the heat of oxidation through the Clausius-Clapeyron Equation.

What we will show is that $0.4-\mathrm{nm}$, ALD ceria films on $\gamma-\mathrm{Al}_{2} \mathrm{O}_{3}$ have thermodynamic redox properties that are different from that of bulk ceria but essentially identical to that reported previously for polycrystalline ceria formed by impregnation into $\gamma-\mathrm{Al}_{2} \mathrm{O}_{3}$. This may be due the film coalescing into particles upon redox cycling. By contrast, the $0.5-\mathrm{nm}$ ceria-zirconia films were stable and very different from either bulk ceria or ceria-zirconia solid solution. The films exhibit evidence for an equilibrium transition between the $\mathrm{Ce}_{0.5} \mathrm{Zr}_{0.5} \mathrm{O}_{2}$ and $\mathrm{Ce}_{0.5} \mathrm{Zr}_{0.5} \mathrm{O}_{1.75}$ phases.

\section{Results}

\subsection{Sample Characterization}

The synthesis and characterization of the $\mathrm{CeO}_{2}(\mathrm{ALD}) / \gamma-\mathrm{Al}_{2} \mathrm{O}_{3}$ and the $\mathrm{CZ}(\mathrm{ALD}) / \gamma-\mathrm{Al}_{2} \mathrm{O}_{3}$ samples have been presented in detail elsewhere [22,23]. Results from Transmission Electron Microscopy (TEM) indicated that the $\gamma-\mathrm{Al}_{2} \mathrm{O}_{3}$ was uniformly covered by the ALD films, and there was good agreement between the thicknesses of the films determined from TEM and value of 0.4-nm estimated from the sample weight changes. By contrast, TEM of a $\mathrm{CeO}_{2}(\mathrm{IMP}) / \gamma-\mathrm{Al}_{2} \mathrm{O}_{3}$ sample with 
the same ceria loading as the ALD sample showed the presence of relatively large $\mathrm{CeO}_{2}$ crystallites that covered only a fraction of alumina surface [22].

The differences between the ALD and impregnated samples are readily apparent from the XRD patterns, shown in Figure 1. All of the samples in this figure were calcined in air to $1073 \mathrm{~K}$ for $2 \mathrm{~h}$ prior to the measurements. To normalize the intensities, $12.5 \mathrm{wt} \%$ carbon was added to each sample and the height of the peak XRD peak at 26.7 degrees $2 \theta$ was fixed. The XRD pattern for the unmodified $\gamma-\mathrm{Al}_{2} \mathrm{O}_{3}$ is shown in Figure 1a for reference. In agreement with the previous report [22], the patterns for the $\mathrm{CeO}_{2}(\mathrm{ALD}) / \gamma-\mathrm{Al}_{2} \mathrm{O}_{3}$ (Figure $1 \mathrm{~b}$ ) and $\mathrm{CeO}_{2}(\mathrm{IMP}) / \gamma-\mathrm{Al}_{2} \mathrm{O}_{3}$ (Figure 1c) samples, both of which had $20 \mathrm{wt} \% \mathrm{CeO}_{2}$, are very different. The diffraction pattern of $\mathrm{CeO}_{2}(\mathrm{ALD}) / \gamma-\mathrm{Al}_{2} \mathrm{O}_{3}$ remained unchanged from that of $\gamma-\mathrm{Al}_{2} \mathrm{O}_{3}$, either because the $\mathrm{CeO}_{2}$ film is amorphous or because the thickness of the $\mathrm{CeO}_{2}$ film is less than the coherence length of the $\mathrm{X}$-rays [22]. By contrast, the $\mathrm{CeO}_{2}(\mathrm{IMP}) / \gamma-\mathrm{Al}_{2} \mathrm{O}_{3}$ shows relatively intense peaks corresponding to the fluorite structure of $\mathrm{CeO}_{2}$.

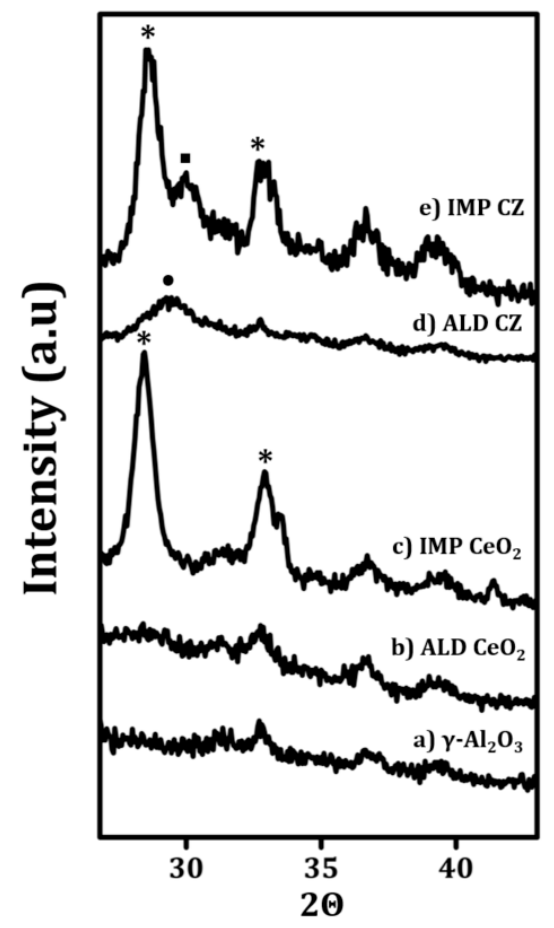

Figure 1. $\mathrm{XRD}$ patterns of (a) $\gamma-\mathrm{Al}_{2} \mathrm{O}_{3}$ support after calcination to $1173 \mathrm{~K}$ in air, and ALD-modified samples, (b) $20 \mathrm{CeO}_{2}-\mathrm{Al}_{2} \mathrm{O}_{3}$ and (d) $20 \mathrm{Ce}_{0.5} \mathrm{Zr}_{0.5} \mathrm{O}_{2}-\mathrm{Al}_{2} \mathrm{O}_{3}$ heated to $1073 \mathrm{~K}$. The patterns in (c) and (e) were obtained from $\mathrm{CeO}_{2}(\mathrm{IMP}) / \mathrm{Al}_{2} \mathrm{O}_{3}$ and $\mathrm{CZ}(\mathrm{IMP}) / \mathrm{Al}_{2} \mathrm{O}_{3}$ respectively. The loadings of materials are the same for the ALD-modified supports and the infiltrated supports. Peaks were normalized to a distinct graphite peak around $2 \theta=26.7^{\circ}$. Characteristic peaks for ceria-zirconia solid solution are marked by $\bullet$, while peaks for $\mathrm{CeO}_{2}$ and $\mathrm{ZrO}_{2}$ are marked by * and $\mathbf{a}$ respectively.

The XRD patterns for the $\mathrm{CZ}(\mathrm{ALD}) / \gamma-\mathrm{Al}_{2} \mathrm{O}_{3}$ (Figure 1d) and $\mathrm{CZ}(\mathrm{IMP}) / \gamma-\mathrm{Al}_{2} \mathrm{O}_{3}$ (Figure 1e) samples, both with $21 \mathrm{wt} \% \mathrm{Ce}_{0.5} \mathrm{Zr}_{0.5} \mathrm{O}_{2}$, are similarly different. There is evidence for a fluorite-related feature at 29.4 degrees $2 \theta$ on the ALD sample; but the feature is very broad and weak, again suggesting that the oxide remains in the form of amorphous film. The peak position, roughly half way between the expected angles for $\mathrm{CeO}_{2}$ and $\mathrm{ZrO}_{2}$, is consistent with formation of a solid, ceria-zirconia solution [28]. Because it is difficult to form a single-phase, ceria-zirconia solid solution by impregnation, the impregnated sample shows two features in this region, at approximately 28 and 30 degrees $2 \theta$, which are due to ceria- and zirconia-rich phases, respectively [28]. Again, the intensities of the peaks on $\mathrm{CZ}(\mathrm{IMP}) / \gamma-\mathrm{Al}_{2} \mathrm{O}_{3}$ are much greater, implying the presence of three-dimensional crystallites.

Because redox cycling, alternating between reducing and oxidizing environments at high temperatures, has been shown to affect ceria crystallite size much more strongly than simple, 
high-temperature calcination [19], we also measured XRD patterns for the $\mathrm{CeO}_{2}(\mathrm{ALD}) / \gamma-\mathrm{Al}_{2} \mathrm{O}_{3}$, $\mathrm{CZ}(\mathrm{ALD}) / \gamma-\mathrm{Al}_{2} \mathrm{O}_{3}$, and $\mathrm{CeO}_{2}(\mathrm{IMP}) / \gamma-\mathrm{Al}_{2} \mathrm{O}_{3}$ samples after redox cycling, with results shown in Figure 2. The $\mathrm{CeO}_{2}(\mathrm{IMP}) / \gamma-\mathrm{Al}_{2} \mathrm{O}_{3}$ sample underwent three cycles of alternating reduction $\left(90 \% \mathrm{H}_{2}\right.$ and $10 \% \mathrm{H}_{2} \mathrm{O}$ for $30 \mathrm{~min}$ ) at $1073 \mathrm{~K}$ and oxidation (dry air for $30 \mathrm{~min}$ ) at $1073 \mathrm{~K}$. The two ALD-prepared samples were used for the thermodynamic measurements that will be discussed later in this paper and were exposed to many oxidation and reduction cycles over a period of several weeks, at temperatures between 873 and $1073 \mathrm{~K}$. Redox cycling significantly narrowed and increased the intensity of the peak at approximately 28 degrees $2 \theta$ on the $\mathrm{CeO}_{2}(\mathrm{IMP}) / \gamma-\mathrm{Al}_{2} \mathrm{O}_{3}$ sample. Using the width at half height of the (220) diffraction peak, the ceria crystallite size on the $\mathrm{CeO}_{2}(\mathrm{IMP}) / \gamma-\mathrm{Al}_{2} \mathrm{O}_{3}$ sample increased from 7 to $18 \mathrm{~nm}$. Redox aging also caused changes in the XRD pattern for the $\mathrm{CeO}_{2}(\mathrm{ALD}) / \gamma-\mathrm{Al}_{2} \mathrm{O}_{3}$ in that the fluorite phase now clearly evident, implying that the film had formed at least some crystallites. However, even after this harsh treatment, the $\mathrm{CeO}_{2}$ crystallite size on the $\mathrm{CeO}_{2}(\mathrm{ALD}) / \gamma-\mathrm{Al}_{2} \mathrm{O}_{3}$ sample was only $5 \mathrm{~nm}$. Furthermore, the intensity of the $\mathrm{CeO}_{2}$ diffraction peak remained much lower than that of even the fresh $\mathrm{CeO}_{2}(\mathrm{IMP}) / \gamma-\mathrm{Al}_{2} \mathrm{O}_{3}$ sample. The $\mathrm{CZ}(\mathrm{ALD}) / \gamma-\mathrm{Al}_{2} \mathrm{O}_{3}$ sample also exhibited a weak peak that can be associated with a $\mathrm{Ce}_{0.5} \mathrm{Zr}_{0.5} \mathrm{O}_{2}$ phase; but, again, this feature is weak in intensity and very broad.

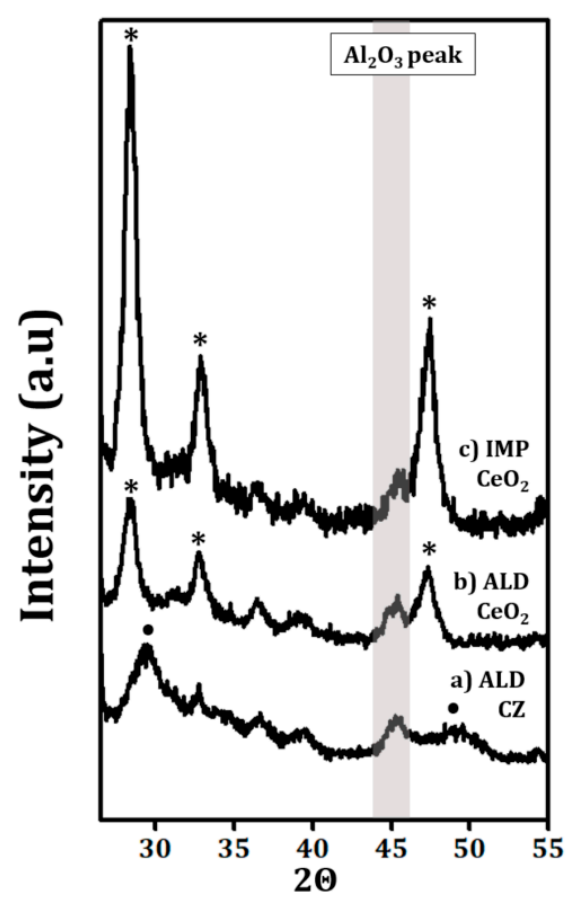

Figure 2. XRD patterns of (a) $20 \mathrm{Ce}_{0.5} \mathrm{Zr}_{0.5} \mathrm{O}_{2}-\mathrm{Al}_{2} \mathrm{O}_{3}$, (b) $20 \mathrm{CeO}_{2}-\mathrm{Al}_{2} \mathrm{O}_{3}$, and (c) $\mathrm{CeO}_{2}$ (IMP) $/ \mathrm{Al}_{2} \mathrm{O}_{3}$ after redox cycling conditions. The $\mathrm{CeO}_{2}(\mathrm{IMP}) / \gamma-\mathrm{Al}_{2} \mathrm{O}_{3}$ sample underwent three cycles of alternating reduction $\left(90 \% \mathrm{H}_{2}\right.$ and $10 \% \mathrm{H}_{2} \mathrm{O}$ for $30 \mathrm{~min}$ ) and oxidation (dry air for $30 \mathrm{~min}$ ) at $1073 \mathrm{~K}$. The ALD-prepared samples, (a) and (b), were exposed to similar oxidation and reduction cycles over a period of several weeks, at temperatures between 873 and $1073 \mathrm{~K}$. Peaks were normalized to a distinct graphite peak around $2 \theta=26.7^{\circ}$. Characteristic peaks for ceria-zirconia solid solution are marked by $\bullet$, while peaks for $\mathrm{CeO}_{2}$ are marked by *.

The sites at the interface between $\mathrm{Pd}$ and ceria are known to be considerably more active for $\mathrm{CO}$ oxidation than either Pd or ceria sites individually [21,29]. Therefore, another indication of how well $\mathrm{CeO}_{2}$ or $\mathrm{Ce}_{0.5} \mathrm{Zr}_{0.5} \mathrm{O}_{2}$ cover the $\gamma-\mathrm{Al}_{2} \mathrm{O}_{3}$ in these composite oxides was gained by adding $\mathrm{Pd}$ to the oxide supports and then measuring $\mathrm{CO}$ oxidation rates. With the exception of the bulk $\mathrm{CeO}_{2}, 1 \mathrm{wt} \%$ $\mathrm{Pd}$ was added to the $\gamma-\mathrm{Al}_{2} \mathrm{O}_{3}, \mathrm{CeO}_{2}$ (ALD) $/ \gamma-\mathrm{Al}_{2} \mathrm{O}_{3}, \mathrm{CeO}_{2}(\mathrm{IMP}) / \gamma-\mathrm{Al}_{2} \mathrm{O}_{3}, \mathrm{CZ}(\mathrm{ALD}) / \gamma-\mathrm{Al}_{2} \mathrm{O}_{3}$, and $\mathrm{CZ}(\mathrm{IMP}) / \gamma-\mathrm{Al}_{2} \mathrm{O}_{3}$ after each of the supports had been calcined at $1073 \mathrm{~K}$ for $2 \mathrm{~h}$. The bulk $\mathrm{CeO}_{2}$ 
was calcined to only $773 \mathrm{~K}$ as it may lose significant surface area after high temperature treatment. After adding the Pd, the catalysts were dried and then calcined to $773 \mathrm{~K}$. BET surface areas and the Pd dispersions, measured after reduction at $673 \mathrm{~K}$, are reported in Table 1; and differential reaction rates are shown in Figure 3. All of the catalysts had similar BET surface areas and Pd dispersions but the catalytic activities varied significantly. To obtain rates under differential conditions, it was therefore necessary to measure them over different temperature ranges. Since the activation energies were similar, it was possible to extrapolate the rates to a common temperature and qualitatively estimate the contact between $\mathrm{Pd}$ and the ceria phase in each sample.

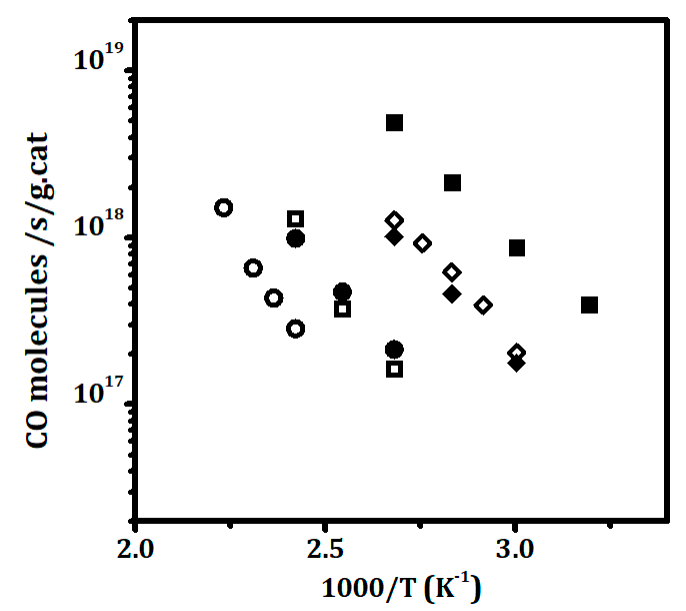

Figure 3. Steady-state, differential reaction rates for $\mathrm{CO}$ oxidation reaction with partial pressure of $\mathrm{CO}$ and $\mathrm{O}_{2}$ at 25 Torr and 12.5 Torr, respectively. The supports were heated at $1073 \mathrm{~K}$ in air for $2 \mathrm{~h}$ before $1 \mathrm{wt} \%$ of $\mathrm{Pd}$ was introduced. After calcination at $773 \mathrm{~K}$ in air, the $\mathrm{CO}$ oxidation rates were compared for the following catalysts: $(\bigcirc)-\mathrm{Pd} / \mathrm{Al}_{2} \mathrm{O}_{3},(\square)-\mathrm{Pd} / \mathrm{CeO}_{2}(\mathrm{IMP}) / \mathrm{Al}_{2} \mathrm{O}_{3},(\bullet)-\mathrm{Pd} / \mathrm{CZ}(\mathrm{IMP}) / \mathrm{Al}_{2} \mathrm{O}_{3}$, $(\diamond) \theta-\mathrm{Pd} / 20 \mathrm{Ce}_{0.5} \mathrm{Zr}_{0.5} \mathrm{O}_{2}-\mathrm{Al}_{2} \mathrm{O}_{3}$, and $(\boldsymbol{\square}) \mathrm{Pd} / 20 \mathrm{CeO}_{2}-\mathrm{Al}_{2} \mathrm{O}_{3}$. The catalyst, $(\diamond)-\mathrm{Pd} / \mathrm{CeO}_{2}$, heated to $773 \mathrm{~K}$ in air, was added for comparison. The $\mathrm{CeO}_{2}$ support was heated to $773 \mathrm{~K}$.

Table 1. Metal Dispersion and BET Surface Area of Catalysts.

\begin{tabular}{ccc}
\hline & Pd Dispersion (\%) & BET Surface Area $\left(\mathbf{m}^{\mathbf{2}} / \mathbf{g}\right)$ \\
\hline $\mathrm{Pd} / \mathrm{Al}_{2} \mathrm{O}_{3}$ & 28 & 96 \\
$\mathrm{Pd} / \mathrm{CeO}_{2}(\mathrm{IMP}) / \mathrm{Al}_{2} \mathrm{O}_{3}$ & 23 & 80 \\
$\mathrm{Pd} / \mathrm{CZ}(\mathrm{IMP}) / \mathrm{Al}_{2} \mathrm{O}_{3}$ & 26 & 82 \\
$\mathrm{Pd} / 20 \mathrm{CeO}_{2}-\mathrm{Al}_{2} \mathrm{O}_{3}$ & 33 & 77 \\
$\mathrm{Pd} / 20 \mathrm{Ce}_{0.5} \mathrm{Zr}_{0.5} \mathrm{O}_{2} / \mathrm{Al}_{2} \mathrm{O}_{3}$ & 34 & 71 \\
$\mathrm{Pd} / \mathrm{CeO}_{2}$ & 40 & 45 \\
\hline
\end{tabular}

First, at $373 \mathrm{~K}$, the $\mathrm{Pd} / \mathrm{CeO}_{2}(\mathrm{ALD}) / \gamma-\mathrm{Al}_{2} \mathrm{O}_{3}$ sample was nearly 100 times more active than $\mathrm{Pd} / \gamma-\mathrm{Al}_{2} \mathrm{O}_{3}$, demonstrating that the $\mathrm{Pd}-\mathrm{CeO}_{2}$ interfacial sites are indeed more active for this reaction. Although the differential rates on $\mathrm{Pd} / \mathrm{CeO}_{2}(\mathrm{ALD}) / \gamma-\mathrm{Al}_{2} \mathrm{O}_{3}$ were also a factor of three higher than those on $\mathrm{Pd} / \mathrm{CeO}_{2}$, this is likely due to the higher surface area of the ALD sample. In any case, the results on $\mathrm{Pd} / \mathrm{CeO}_{2}(\mathrm{ALD}) / \gamma-\mathrm{Al}_{2} \mathrm{O}_{3}$ suggest that all of the $\mathrm{Pd}$ is in contact with $\mathrm{CeO}_{2} \mathrm{ALD}$ film and that the $\mathrm{CeO}_{2}$ must cover the entire surface of the support. This is the same conclusion reached earlier from WGS measurements on similar samples [22]. The Pd/CZ(ALD) $/ \gamma-\mathrm{Al}_{2} \mathrm{O}_{3}$ catalyst exhibited rates similar to that found on $\mathrm{Pd} / \mathrm{CeO}_{2}$ and the two impregnated samples showed activities closer to that of $\mathrm{Pd} / \gamma-\mathrm{Al}_{2} \mathrm{O}_{3}$. These results imply that $\mathrm{Pd}$ is not in good contact with the ceria phases on the supports prepared by impregnation. The lower activity of $\mathrm{Pd} / \mathrm{CZ}(\mathrm{ALD}) / \gamma-\mathrm{Al}_{2} \mathrm{O}_{3}$ compared to $\mathrm{Pd} / \mathrm{CeO}_{2}(\mathrm{ALD}) / \gamma-\mathrm{Al}_{2} \mathrm{O}_{3}$ may be due to the fact that the presence of $\mathrm{ZrO}_{2}$ decreases contact area between $\mathrm{Pd}$ and $\mathrm{CeO}_{2}$ in the $\mathrm{Pd} / \mathrm{CZ}(\mathrm{ALD}) / \gamma-\mathrm{Al}_{2} \mathrm{O}_{3}$ sample. 


\subsection{Thermodynamic Measurements}

Thermodynamic measurements were performed on the bulk $\mathrm{Ce}_{0.5} \mathrm{Zr}_{0.5} \mathrm{O}_{2}$, the $\mathrm{CeO}_{2}$ (ALD) $/ \gamma-\mathrm{Al}_{2} \mathrm{O}_{3}$, and the $\mathrm{CZ}(\mathrm{ALD}) / \gamma-\mathrm{Al}_{2} \mathrm{O}_{3}$ samples after each sample has been calcined to $1073 \mathrm{~K}$ for $2 \mathrm{~h}$. To determine the maximum extents of reduction in the $\mathrm{CeO}_{2}$ (ALD) $/ \gamma-\mathrm{Al}_{2} \mathrm{O}_{3}$ and the $\mathrm{CZ}(\mathrm{ALD}) / \gamma-\mathrm{Al}_{2} \mathrm{O}_{3}$ samples, the samples were initially exposed to dry, flowing $\mathrm{H}_{2}$ at $973 \mathrm{~K}$ in the flow-titration system. Assuming that all the oxygen which could be reversibly removed was due to reduction of $\mathrm{Ce}^{4+}$ to $\mathrm{Ce}^{3+}$, the calculated $\mathrm{O}: \mathrm{Ce}$ ratio for both samples was 1.55 after reduction. This value did not change with repeated oxidation-reduction cycles and differs from the value expected for complete reduction by $10 \%$. The probable reason for the discrepancy is the uncertainty in the ceria loading (e.g., Sample weights can be difficult to measure due to water adsorption upon exposure to laboratory air). The result demonstrates that the ceria in the ALD films is fully reducible.

The thermodynamic, redox properties of the $\mathrm{CeO}_{2}(\mathrm{ALD}) / \gamma-\mathrm{Al}_{2} \mathrm{O}_{3}$ sample were measured using both flow-titration (the solid data points) and coulometric-titration (the unfilled points) measurements; and a plot of the cerium oxygen stoichiometry as a function of $P_{\mathrm{O}_{2}}$ is shown in Figure 4. For comparison purposes, the figure also includes data from earlier work on bulk ceria and from an impregnated, $30 \mathrm{wt} \%$ ceria on La-treated $\mathrm{Al}_{2} \mathrm{O}_{3}$ (shown in the inset) [19]. Flow-titration measurements were performed at 873,973 , and $1073 \mathrm{~K}$ but coulometric-titration was performed only at $1073 \mathrm{~K}$ on this sample. The data at $1073 \mathrm{~K}$ showed that there was good agreement between the two techniques in the $P_{\mathrm{O}_{2}}$ range where the measurements overlapped. The redox thermodynamics for the $\mathrm{CeO}_{2}(\mathrm{ALD}) / \gamma-\mathrm{Al}_{2} \mathrm{O}_{3}$ sample differ dramatically from that for bulk ceria. As noted in previous publications, bulk ceria is very difficult to reduce [30]. Of equal interest, the thermodynamic data for the $\mathrm{CeO}_{2}$ (ALD) $/ \gamma-\mathrm{Al}_{2} \mathrm{O}_{3}$ sample are remarkably similar to the previously published data for impregnated ceria on La-doped alumina in regions where the $P_{\mathrm{O}_{2}}$ values overlap. For example, at $973 \mathrm{~K}$ and a $P_{\mathrm{O}_{2}}$ of $10^{-20} \mathrm{~atm}$, the O:Ce ratio was close to 1.75 on both samples. Similarly, at $873 \mathrm{~K}$ and a $P_{\mathrm{O}_{2}}$ of $10^{-25} \mathrm{~atm}$, the O:Ce ratio was close to 1.78 on both samples. As shown by the earlier XRD data, the $\mathrm{CeO}_{2}$ (ALD) $/ \gamma-\mathrm{Al}_{2} \mathrm{O}_{3}$ showed some formation of $\mathrm{CeO}_{2}$ crystallites upon redox cycling, but the crystallites on the ALD-prepared sample were clearly much smaller. The fact that the thermodynamic data did not change would suggest that equilibrium data is not a strong function of crystallite size, at least over the range of crystallite sizes investigated here.

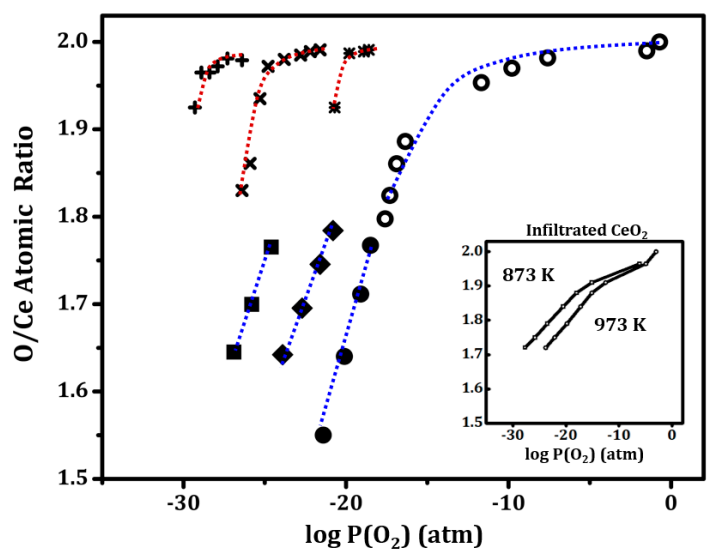

Figure 4. Oxidation isotherms for $20 \mathrm{CeO}_{2}-\mathrm{Al}_{2} \mathrm{O}_{3}$ at selected temperatures $(873 \mathrm{~K}, 973 \mathrm{~K}, 1073 \mathrm{~K})$. The results for pure ceria were obtained from a previous publication from our group [19], and were determined by flow titration at $(+)-873 \mathrm{~K},(\times)-973 \mathrm{~K}$, and $\left(^{*}\right)-1073 \mathrm{~K}$. The $(\boldsymbol{\square}),(\boldsymbol{\Lambda})$, and $(\bullet)$ symbols show the isotherms for $20 \mathrm{CeO}_{2}-\mathrm{Al}_{2} \mathrm{O}_{3}$ determined by flow titration at $873 \mathrm{~K}, 973 \mathrm{~K}$ and $1073 \mathrm{~K}$ respectively. The $(\bigcirc)$ symbol shows the isotherm for $20 \mathrm{CeO}_{2}-\mathrm{Al}_{2} \mathrm{O}_{3}$ determined by coulometric titration at $1073 \mathrm{~K}$. For comparison, previous results for infiltrated ceria on alumina-based support obtained from coulometric titration at $873 \mathrm{~K}$ and $973 \mathrm{~K}$ are shown [19]. 
The oxidation isotherms for bulk $\mathrm{Ce}_{0.5} \mathrm{Zr}_{0.5} \mathrm{O}_{2}$ and for $\mathrm{CZ}(\mathrm{ALD}) / \gamma-\mathrm{Al}_{2} \mathrm{O}_{3}$ are shown in Figure 5. Results for the bulk $\mathrm{Ce}_{0.5} \mathrm{Zr}_{0.5} \mathrm{O}_{2}$ were only measured at $1073 \mathrm{~K}$ but the data again agree well with previously published data for a sample with this composition in regions where measurements were previously performed [27]. Similar to results for bulk $\mathrm{CeO}_{2}$ and $\mathrm{CeO}_{2}(\mathrm{ALD}) / \gamma-\mathrm{Al}_{2} \mathrm{O}_{3}$, the equilibrium oxygen stoichiometry in the bulk $\mathrm{Ce}_{0.5} \mathrm{Zr}_{0.5} \mathrm{O}_{2}$ sample varied gradually with the $P_{\mathrm{O}_{2}}$. The data for the $\mathrm{CZ}(\mathrm{ALD}) / \gamma-\mathrm{Al}_{2} \mathrm{O}_{3}$ sample were significantly different. First, flow titration was not useful in measuring the properties for the $\mathrm{CZ}(\mathrm{ALD}) / \gamma-\mathrm{Al}_{2} \mathrm{O}_{3}$ sample because the sample was completely reduced at all experimentally accessible $\mathrm{H}_{2} \mathrm{O}: \mathrm{H}_{2}$ ratios between $873 \mathrm{~K}$ and $1073 \mathrm{~K}$. It was therefore necessary to measure the equilibrium isotherms at 873 and $1073 \mathrm{~K}$ using coulometric titration. Interestingly, the isotherms at both temperatures were nearly vertical lines, which is an indication that there is equilibrium between two well-defined compounds. The transitions for reduction of $\mathrm{Ce}^{4+}$ to the $\mathrm{Ce}^{3+}$ states occur at $P_{\mathrm{O}_{2}}$ of approximately $10^{-9} \mathrm{~atm}$ at $1073 \mathrm{~K}$ and $10^{-15}$ atm at $873 \mathrm{~K}$. These values are much higher than the equilibrium $P_{\mathrm{O}_{2}}$ for the $\mathrm{CeO}_{2}$ (ALD) $/ \gamma-\mathrm{Al}_{2} \mathrm{O}_{3}$ sample, showing that the mixed oxide is much easier to reduce.

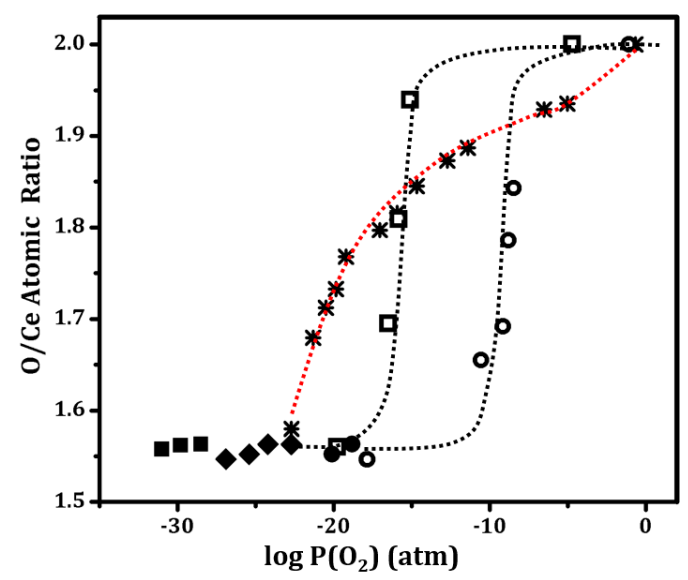

Figure 5. $\mathrm{O} / \mathrm{Ce}$ ratio as a function of $\mathrm{P}\left(\mathrm{O}_{2}\right)$ for $20 \mathrm{Ce}_{0.5} \mathrm{Zr}_{0.5} \mathrm{O}_{2}-\mathrm{Al}_{2} \mathrm{O}_{3}$, determined by flow titration, at temperatures $(\diamond)-773 \mathrm{~K},(\mathbf{\square})-873 \mathrm{~K}$, and $(\bullet)-1073 \mathrm{~K}$. The $(\bigcirc)$ symbol shows the isotherm for $20 \mathrm{Ce}_{0.5} \mathrm{Zr}_{0.5} \mathrm{O}_{2}-\mathrm{Al}_{2} \mathrm{O}_{3}$, determined by coulometric titration at $1073 \mathrm{~K}$. Oxidation isotherm result for pure ceria-zirconia $\left(\mathrm{Ce}_{0.5} \mathrm{Zr}_{0.5} \mathrm{O}_{2}\right)$ are obtained by flow titration at $\left({ }^{*}\right)-1073 \mathrm{~K}$, and the result is consistent with previous literature [26].

Heats of oxidation can be calculated from the temperature dependence of the isotherm using Equation (1):

$$
-\Delta H=R \frac{\partial \ln P\left(\mathrm{O}_{2}\right)}{\partial \frac{1}{T}}
$$

The heats, $-\Delta H$, calculated from this equation and the data in Figures 4 and 5 are plotted in Figure 6, together with previously reported numbers for $\mathrm{CeO}_{2}$ supported on $\mathrm{La}_{-} \mathrm{Al}_{2} \mathrm{O}_{3}[19]$ and for bulk $\mathrm{Ce}_{0.5} \mathrm{Zr}_{0.5} \mathrm{O}_{2}$ [26]. The heats of oxidation for both the $\mathrm{CeO}_{2}$ (ALD) $/ \gamma-\mathrm{Al}_{2} \mathrm{O}_{3}$ and $\mathrm{CZ}$ (ALD) $/ \gamma-\mathrm{Al}_{2} \mathrm{O}_{3}$ samples were between 550 and $600 \mathrm{~kJ} / \mathrm{mol} \mathrm{O}_{2}$, independent of the extent of reduction. This is much lower than the reported heat of oxidation for bulk $\mathrm{CeO}_{2}, 760 \mathrm{~kJ} / \mathrm{mol} \mathrm{O}_{2}$. In the previous study of impregnated $\mathrm{CeO}_{2}$ on La-doped $\mathrm{Al}_{2} \mathrm{O}_{3},-\Delta H$ was reported to vary with stoichiometry, increasing from $500 \mathrm{~kJ} / \mathrm{mol} \mathrm{O}_{2}$ at low extents of reduction and to a value close to that of the bulk oxide at high reduction levels. $-\Delta H$ for $\mathrm{Ce}_{0.5} \mathrm{Zr}_{0.5} \mathrm{O}_{2}$ were reported to be in the range of $500 \mathrm{~kJ} / \mathrm{mol} \mathrm{O}_{2}$. The uncertainty in the calculated $-\Delta H$ is relatively high, perhaps $\sim 50 \mathrm{~kJ} / \mathrm{mol}$, when the oxide stoichiometry varies with $P_{\mathrm{O}_{2}}$, as it does for the $\mathrm{CeO}_{2}$ (ALD) $/ \gamma-\mathrm{Al}_{2} \mathrm{O}_{3}$ sample. However, when the isotherm is a vertical line, as with the $\mathrm{CZ}(\mathrm{ALD}) / \gamma-\mathrm{Al}_{2} \mathrm{O}_{3}$ sample, the uncertainty is much less. Therefore, we suggest that the oxidation enthalpies for all of these catalysts may be similar, at least for low extents of reduction. 


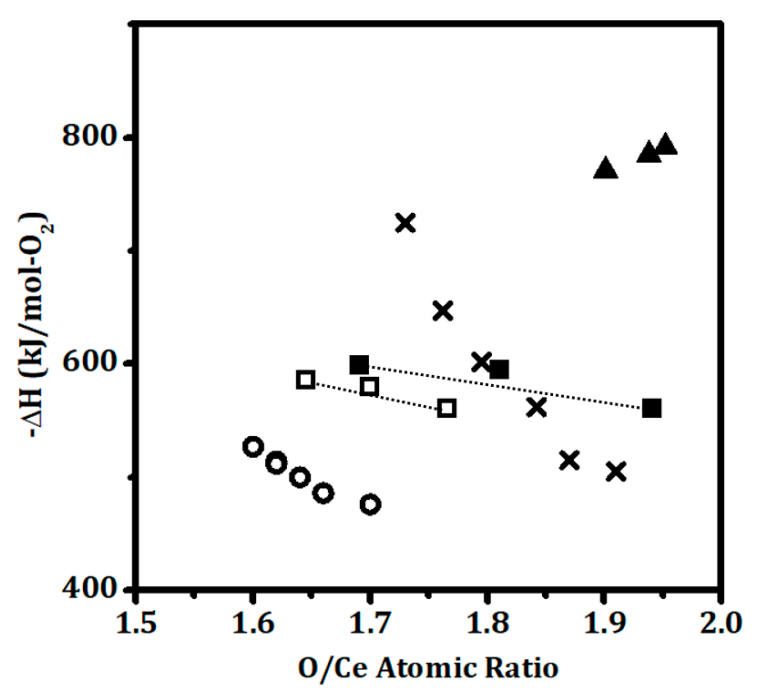

Figure 6. $-\Delta H$ of oxidation as a function of $\mathrm{O} / \mathrm{Ce}$ ratio for $(\boldsymbol{\square})-20 \mathrm{Ce}_{0.5} \mathrm{Zr}_{0.5} \mathrm{O}_{2}-\mathrm{Al}_{2} \mathrm{O}_{3}$ and $(\square)-20 \mathrm{CeO}_{2}-\mathrm{Al}_{2} \mathrm{O}_{3}$. Results for $(\boldsymbol{\Lambda})$ - bulk $\mathrm{CeO}_{2},(\bigcirc)$ - bulk $\mathrm{Ce}_{0.5} \mathrm{Zr}_{0.5} \mathrm{O}_{2}$, and $(\times)$-infiltrated $\mathrm{CeO}_{2}$ on alumina-based support are obtained from previous work for comparison [19].

\section{Discussion}

The results in this paper demonstrate that novel ceria and ceria-zirconia supports can be prepared by ALD onto stable supports. In particular, the thin films grown on $\gamma-\mathrm{Al}_{2} \mathrm{O}_{3}$ are shown to be stable to high temperature sintering and relatively immune to redox cycling. The ALD-grown materials are structurally very different from materials having the same compositions but prepared by conventional impregnation. Not only do the ALD films form a more uniform coverage over the $\gamma-\mathrm{Al}_{2} \mathrm{O}_{3}$ support but one can more easily form mixed oxides like $\mathrm{Ce}_{0.5} \mathrm{Zr}_{0.5} \mathrm{O}_{2}$ without the use of chelating agents, like citric acid.

Since there was no loss in reducibility upon redox cycling on any of the samples, $\mathrm{CeAlO}_{3}$ formation does not appear to be a serious issue with these materials. However, there was evidence of $\mathrm{CeO}_{2}$ crystallite growth on the $\mathrm{CeO}_{2}(\mathrm{ALD}) / \gamma-\mathrm{Al}_{2} \mathrm{O}_{3}$ sample under redox cycling. This may be partly due to differences in the "wetting" properties of $\mathrm{CeO}_{2}$ and $\mathrm{Ce}_{2} \mathrm{O}_{3}$ on $\gamma-\mathrm{Al}_{2} \mathrm{O}_{3}$ or it may be due to the expansion and contraction that must occur in the film upon oxidation and reduction. If wetting issues dominate, it may be possible to stabilize the $\mathrm{CeO}_{2}$ films by using something other than $\gamma-\mathrm{Al}_{2} \mathrm{O}_{3}$ as the underlying support; if expansion-contraction issue are responsible, the underlying support will probably not matter. It is interesting that the ceria-zirconia film in the $\mathrm{CZ}$ (ALD) $/ \gamma-\mathrm{Al}_{2} \mathrm{O}_{3}$ sample appears to be more stable but the reasons for this are still uncertain.

The thin $\mathrm{Ce}_{0.5} \mathrm{Zr}_{0.5} \mathrm{O}_{2}$ film on the $\mathrm{CZ}(\mathrm{ALD}) / \gamma-\mathrm{Al}_{2} \mathrm{O}_{3}$ sample appears to exhibit different equilibrium $P_{\mathrm{O}_{2}}$ from that of bulk $\mathrm{Ce}_{0.5} \mathrm{Zr}_{0.5} \mathrm{O}_{2}$. While this could be due to surface energies, we suggest that it may also due to the confined geometry of the film. In previous work with bulk ceria-zirconia mixed oxides [31], it was argued that the shape of the isotherm results primarily from changes in the entropy of oxidation, rather than changes in the heats of oxidation. This conclusion was based on the fact that $-\Delta H$ was found to be independent of the extent of reduction. To explain how the oxidation entropy would change with the extent of reduction while the enthalpy was constant, it was suggested that each lattice oxygen that is adjacent to a pair of $\mathrm{Ce}^{4+}$ ions is energetically equivalent. However, since it should be energetically difficult to remove a lattice oxygen that is next to a vacancy, the number of possible oxygens that can be removed next to each set of adjacent $\mathrm{Ce}^{4+}$ ions will decrease as the solid becomes progressively reduced. In a film that is less than one unit cell in thickness, there is no possibility for adjacent vacancies and $-\Delta G$ could be independent of the extent of reduction. According to this hypothesis, the equilibrium properties of ceria-zirconia films should change with thickness, a possibility that would be interesting to test in future work. 
Obviously, there is still much to learn about the properties of thin ceria and ceria-zirconia films prepared by ALD. The materials clearly show interesting properties as catalyst supports. Studying their redox properties may help to elucidate how surfaces and interfaces with other oxides affect thermodynamic equilibria.

\section{Experimental Methods}

\subsection{Sample Preparation and Characterization}

Samples were prepared by both ALD and conventional impregnation methods, using $\gamma-\mathrm{Al}_{2} \mathrm{O}_{3}$ (Strem Chemicals, Inc., Newburyport, MA, USA) as a support that had been calcined at $1173 \mathrm{~K}$ and had a BET surface area of $130 \mathrm{~m}^{2} / \mathrm{g}$. The ALD-prepared samples were synthesized in a home-built apparatus using very similar methods to that described in previous work [32]. Briefly, the ALD cycle consisted of exposing the evacuated $\gamma-\mathrm{Al}_{2} \mathrm{O}_{3}$ substrate to a few Torr of the organometallic precursors, either Ce(TMHD) ${ }_{4}$ (Strem Chemicals, Inc.) or Zr(TMHD) $)_{4}$ (Strem Chemicals, Inc.), at $503 \mathrm{~K}$ for $300 \mathrm{~s}$, followed by evacuation to $\sim 50$ millitorr and precursor oxidation. It should be noted that the substrate was exposed to each gaseous precursor for multiple times to ensure surface saturation. One change in the present study from that in previous work was that precursor oxidation was performed at $503 \mathrm{~K}$ for $300 \mathrm{~s}$ using an $\mathrm{O}_{2}$ plasma generated by adding $\sim 100$ Torr of $\mathrm{O}_{2}$ to the substrate chamber, followed by contacting a tesla coil to a $\mathrm{Cu}$ wire that was wrapped around the substrate chamber. Oxidation using a plasma has previously been shown to be very effective at removing difficult-to-oxidize species at low temperatures [33]. To ensure that the ligands were completely oxidized, we removed each sample from the system after every 5 cycles and then heated it to $673 \mathrm{~K}$ in a muffle furnace for $5 \mathrm{~min}$. Growth rates for both $\mathrm{CeO}_{2}(0.016 \mathrm{~nm} /$ cycle $)$ and $\mathrm{ZrO}_{2}(0.024 \mathrm{~nm} /$ cycle $)$ were determined by measuring the sample mass after every five cycles and were identical to that which was reported in earlier publications from our laboratory [22,23]. The present study focused on just two ALD-prepared samples: a $\mathrm{CeO}_{2} / \gamma-\mathrm{Al}_{2} \mathrm{O}_{3}$ made with 20 ALD cycles of ceria $\left(20 \mathrm{wt} \% \mathrm{CeO}_{2}, \mathrm{CeO}_{2}(\mathrm{ALD}) / \gamma-\mathrm{Al}_{2} \mathrm{O}_{3}\right.$ ) and a $\mathrm{Ce}_{0.5} \mathrm{Zr}_{0.5} \mathrm{O}_{2} / \gamma-\mathrm{Al}_{2} \mathrm{O}_{3}$ made with 12 ALD cycles of ceria and 8 ALD cycles of zirconia $(21 \mathrm{wt} \%$ $\mathrm{Ce}_{0.5} \mathrm{Zr}_{0.5} \mathrm{O}_{2}, \mathrm{CZ}(\mathrm{ALD}) / \gamma-\mathrm{Al}_{2} \mathrm{O}_{3}$ ). In both samples, the films were estimated to be $0.4-\mathrm{nm}$ thick, based on the sample weight changes, assuming a uniform film over the entire alumina surface.

Conventional alumina-supported catalysts containing $20 \mathrm{wt} \% \mathrm{CeO}_{2}\left(\mathrm{CeO}_{2}(\mathrm{IMP}) / \gamma-\mathrm{Al}_{2} \mathrm{O}_{3}\right)$ or $21 \mathrm{wt} \%$ of a $\mathrm{CeO}_{2}-\mathrm{ZrO}_{2}$ mixture (CZ(IMP) $/ \gamma-\mathrm{Al}_{2} \mathrm{O}_{3}$ ) were prepared by infiltration with aqueous solutions of cerium (III) nitrate hexahydrate $\left(\mathrm{Ce}\left(\mathrm{NO}_{3}\right)_{3} \cdot 6 \mathrm{H}_{2} \mathrm{O}\right.$, Sigma Aldrich, St. Louis, MO, USA) or a mixture of zirconium oxynitrate hydrate $\left(\mathrm{ZrO}\left(\mathrm{NO}_{3}\right)_{2} \cdot x \mathrm{H}_{2} \mathrm{O}\right.$, Sigma Aldrich, degree of hydration of fresh bottle $\sim 6$ ) and $\mathrm{Ce}\left(\mathrm{NO}_{3}\right)_{3} \cdot 6 \mathrm{H}_{2} \mathrm{O}$. The samples were then dried at $333 \mathrm{~K}$ overnight, followed by calcination to $673 \mathrm{~K}$ for $6 \mathrm{~h}$ to remove the remaining nitrates. Bulk $\mathrm{CeO}_{2}$ was prepared by precipitating an aqueous solution of $\mathrm{Ce}\left(\mathrm{NO}_{3}\right)_{3} \cdot 6 \mathrm{H}_{2} \mathrm{O}$ with excess ammonium hydroxide $\left(\mathrm{NH}_{4} \mathrm{OH}\right.$, Fisher Scientific, Hampton, NH, USA), then drying the sample overnight at $333 \mathrm{~K}$ followed by calcination at $773 \mathrm{~K}$ for $6 \mathrm{~h}$ [22]. Bulk $\mathrm{Ce}_{0.5} \mathrm{Zr}_{0.5} \mathrm{O}_{2}$ was prepared by first dissolving stoichiometric amounts of $\mathrm{Ce}\left(\mathrm{NO}_{3}\right)_{3}$ and $\mathrm{ZrO}\left(\mathrm{NO}_{3}\right)_{2}$ in distilled water. The aqueous mixture was titrated at a rate of $5 \mathrm{~mL} / \mathrm{min}$ into a solution of ammonium hydroxide, while stirring. The precipitate was allowed to dry overnight at $333 \mathrm{~K}$, followed by calcination to $773 \mathrm{~K}$ for $6 \mathrm{~h}$ [23].

Samples containing $1 \mathrm{wt} \% \mathrm{Pd}$ were prepared by incipient wetness using aqueous solutions of tetraaminepalladium(II) nitrate (Sigma Aldrich). The materials were dried overnight at $333 \mathrm{~K}$ and calcined at $773 \mathrm{~K}$ in air for $6 \mathrm{~h}$ to remove any organics and nitrates. It is noteworthy that the ceria-containing samples prepared by ALD were relatively hydrophobic, a fact that has been reported previously for flat surfaces modified by $\mathrm{CeO}_{2} \mathrm{ALD}$ [34]. However, the aqueous solutions did slowly absorb into the powders and the preparation procedure for adding Pd was the same except for the time required to impregnate.

X-ray Diffraction (XRD) patterns were recorded on a Rigaku Smartlab diffractometer (Toyko, Japan) equipped with a $\mathrm{Cu} \mathrm{K} \alpha$ source $(\lambda=0.15416 \mathrm{~nm})$. Crystalline graphite, physically mixed with the 
samples in a ratio of 1:8, was used as a reference for the peak positions in XRD. The Pd dispersions were determined by $\mathrm{CO}$ chemisorption at room temperature on the reduced catalysts. In this procedure, the samples were first oxidized in 200 Torr $\mathrm{O}_{2}$ at $673 \mathrm{~K}$ and reduced in 200 Torr $\mathrm{H}_{2}$ at $673 \mathrm{~K}$ before measuring CO uptakes. Dispersions were calculated assuming one CO per surface Pd.

Steady-state rates for $\mathrm{CO}$ oxidation were measured under differential conditions in a quartz-tube, flow reactor using 25 Torr $\mathrm{CO}$ and 12.5 Torr $\mathrm{O}_{2}$. The total flow rate of He was maintained at $60 \mathrm{~mL} / \mathrm{min}$ and the mass of catalyst was $0.10 \mathrm{~g}$. Products were analyzed using a gas chromatograph (SRI8610C) (Torrance, CA, USA) equipped with a Hayesep Q column and a TCD detector. All rates in this study were normalized to the mass of the catalyst. Differential conversions were maintained in all cases.

\subsection{Redox Equilibrium Measurements}

Equilibrium oxidation isotherms were obtained by both flow titration and coulometric titration. In flow titration, the oxidation state of the catalyst is measured by determining the amount of oxygen required to completely re-oxidize the sample after it has been equilibrated at a given $P_{\mathrm{O}_{2}}$. While the equilibrium stoichiometry for a specified $\mathrm{H}_{2}-\mathrm{H}_{2} \mathrm{O}$ ratio was the same whether starting from an oxidized or a reduced sample, we found that equilibrium was achieved more rapidly starting from the reduced form. Therefore, the experiments were performed in the following manner: $0.5 \mathrm{~g}$ of sample were placed in a quartz-tube flow reactor, exposed to dry flowing $\mathrm{H}_{2}(30 \mathrm{~mL} / \mathrm{min})$ at the temperature of interest for $0.5 \mathrm{~h}$, and then exposed to a flowing $\mathrm{H}_{2}-\mathrm{H}_{2} \mathrm{O}$ mixture $(30 \mathrm{~mL} / \mathrm{min})$ for $1 \mathrm{~h}$. The $\mathrm{H}_{2}-\mathrm{H}_{2} \mathrm{O}$ mixture was produced by passing $\mathrm{H}_{2}$ through a temperature-controlled water bubbler, using the equilibrium vapor pressure to calculate the $\mathrm{H}_{2} \mathrm{O}$ partial pressure. After purging the sample with dry He for $0.5 \mathrm{~h}$, flowing air $\left(21 \% \mathrm{O}_{2}\right.$ and $79 \% \mathrm{~N}_{2}$, Airgas) was passed over the sample at a rate of $3.1 \mathrm{~mL} / \mathrm{min}$ and the composition of the effluent gas was determined using a quadrupole mass spectrometer. The amount of oxygen required to re-oxidize the sample was obtained by integrating the difference between the $\mathrm{N}_{2}$ and $\mathrm{O}_{2}$ signals. This in turn provides the oxidation state of the ceria that had been in equilibrium with the $\mathrm{H}_{2}-\mathrm{H}_{2} \mathrm{O}$ mixture.

Because the $\mathrm{H}_{2}-\mathrm{H}_{2} \mathrm{O}$ ratio can only be controlled over a limited range in flow titration, coulometric titration was also used to verify the flow-titration data and to extend the range of $P_{\mathrm{O}_{2}}$ equilibrium measurements [19]. In coulometric titration, a $0.5 \mathrm{~g}$ sample was inserted into a YSZ (yttria-stabilized zirconia) tube that had Ag electrodes painted on both inside and outside. The YSZ tube was then placed in a horizontal tube furnace and then heated to the temperature of interest, either $873 \mathrm{~K}$ or $1073 \mathrm{~K}$, using a heating rate of $1.0 \mathrm{~K} / \mathrm{min}$. During the temperature ramp, a mixture of $5 \% \mathrm{O}_{2}, 10 \% \mathrm{H}_{2} \mathrm{O}$, and $85 \%$ Ar was allowed to flow over the sample at a flow rate of $110 \mathrm{~mL} / \mathrm{min}$ in order to ensure that the sample was completely oxidized at the start of the measurements. After $1 \mathrm{~h}$ at the temperature of interest, the flow was stopped and the ends of the YSZ tube were sealed with Cajon fittings. Specified amounts of oxygen were then electrochemically pumped from the inside of the YSZ tube by applying a current across the electrodes using a Gamry instruments potentiostat. After allowing the system to come to equilibrium with the electrodes at open circuit, the equilibrium $P_{\mathrm{O}_{2}}$ was calculated from the Nernst equation and the open circuit potential. To demonstrate equilibrium, oxidation isotherms were also measured starting with the reduced sample.

\section{Conclusions}

Atomic Layer Deposition (ALD) of $\mathrm{CeO}_{2}$ and $\mathrm{Ce}_{0.5} \mathrm{Zr}_{0.5} \mathrm{O}_{2}$ films on $\gamma-\mathrm{Al}_{2} \mathrm{O}_{3}$ produces materials in which the alumina surface is coated with either ceria or a ceria-zirconia mixed oxide. The films exhibit good thermal stability upon oxidation and are also reasonably stable to redox cycling. Although the thermodynamic, redox properties of the $\mathrm{CeO}_{2}$ films prepared by ALD were similar to those of a sample prepared by impregnation, the ALD samples showed better catalytic properties as supports for Pd due to improved contact between the ceria and the Pd. Thermodynamic measurements on the mixed-oxide film indicated that solid solutions were formed and these were much more easily reduced than normal ceria. 
Acknowledgments: Tzia Ming Onn and Raymond J. Gorte are grateful to the Department of Energy, Office of Basic Energy Sciences, Chemical Sciences, Geosciences and Biosciences Division, Grant No. DE-FG02-13ER16380 for support of this work.

Author Contributions: Tzia Ming Onn and Raymond J. Gorte conceived and designed the experiments; Xinyu Mao, Chao Lin, and Cong Wang performed the experiments; Tzia Ming Onn and Raymond J. Gorte analyzed the data; Tzia Ming Onn and Raymond J. Gorte wrote the paper.

Conflicts of Interest: The authors declare no conflict of interest.

\section{References}

1. Montini, T.; Melchionna, M.; Monai, M.; Fornasiero, P. Fundamentals and catalytic applications of $\mathrm{CeO}_{2}$-based materials. Chem. Rev. 2016, 116, 5987-6041. [CrossRef] [PubMed]

2. Fino, D.; Bensaid, S.; Piumetti, M.; Russo, N. A review on the catalytic combustion of soot in diesel particulate filters for automotive applications: from powder catalysts to structured reactors. Appl. Catal. A 2016, 509, 75-96. [CrossRef]

3. Shelef, M.; Graham, G.W.; McCabe, R.W. Ceria and other oxygen storage components in automotive catalysts. In Catalysis by Ceria and Related Materials; Imperial College Press: London, UK, 2002; Volume 2, pp. 343-375.

4. Gandhi, H.; Graham, G.; McCabe, R.W. Automotive exhaust catalysis. J. Catal. 2003, 216, 433-442. [CrossRef]

5. Sugiura, M.; Ozawa, M.; Suda, A.; Suzuki, T.; Kanazawa, T. Development of innovative three-way catalysts containing ceria-zirconia solid solutions with high oxygen storage/release capacity. Bull. Chem. Soc. Jpn. 2005, 78, 752-767. [CrossRef]

6. Gorte, R.J. Ceria in catalysis: from automotive applications to the water-gas shift reaction. AIChE J. 2010, 56, 1126-1135. [CrossRef]

7. Li, J.; Liu, X.; Zhan, W.; Guo, Y.; Guo, Y.; Lu, G. Preparation of high oxygen storage capacity and thermally stable ceria-zirconia solid solution. Catal. Sci. Technol. 2016, 6, 897-907. [CrossRef]

8. Sharma, S.; Hilaire, S.; Vohs, J.; Gorte, R.J.; Jen, H.-W. Evidence for oxidation of ceria by $\mathrm{CO}_{2}$. J. Catal. 2000, 190, 199-204. [CrossRef]

9. Heck, R.M.; Farrauto, R.J. Automobile exhaust catalysts. Appl. Catal. A 2001, 221, 443-457. [CrossRef]

10. Bueno-Lopez, A.; Krishna, K.; Makkee, M.; Moulijn, J.A. Active oxygen from $\mathrm{CeO}_{2}$ and its role in catalysed soot oxidation. Catal. Lett. 2005, 99, 203-205. [CrossRef]

11. Bunluesin, T.; Gorte, R.J.; Graham, G. Studies of the water-gas-shift reaction on ceria-supported Pt, Pd, and Rh: Implications for oxygen-storage properties. Appl. Catal. B 1998, 15, 107-114. [CrossRef]

12. Hilaire, S.; Wang, X.; Luo, T.; Gorte, R.J.; Wagner, J. A comparative study of water-gas-shift reaction over ceria supported metallic catalysts. Appl. Catal. A 2001, 215, 271-278. [CrossRef]

13. Fu, Q.; Saltsburg, H.; Flytzani-Stephanopoulos, M. Active nonmetallic Au and Pt species on ceria-based water-gas shift catalysts. Science 2003, 301, 935-938. [CrossRef] [PubMed]

14. Colussi, S.; Katta, L.; Amoroso, F.; Farrauto, R.J.; Trovarelli, A. Ceria-based palladium zinc catalysts as promising materials for water gas shift reaction. Catal. Commun. 2014, 47, 63-66. [CrossRef]

15. Wang, X.; Gorte, R.J. A study of steam reforming of hydrocarbon fuels on Pd/ceria. Appl. Catal. A 2002, 224, 209-218. [CrossRef]

16. Duarte, R.; Safonova, O.; Krumeich, F.; Makosch, M.; Van Bokhoven, J. Oxidation state of Ce in $\mathrm{CeO}_{2}$-promoted $\mathrm{Rh} / \mathrm{Al}_{2} \mathrm{O}_{3}$ catalysts during methane steam reforming: $\mathrm{H}_{2} \mathrm{O}$ activation and alumina stabilization. ACS Catal. 2013, 3, 1956-1964. [CrossRef]

17. Divins, N.; Casanovas, A.; Xu, W.; Senanayake, S.; Wiater, D.; Trovarelli, A.; Llorca, J. The influence of nano-architectured $\mathrm{CeO}_{x}$ supports in $\mathrm{Rh} \mathrm{Pd} / \mathrm{CeO}_{2}$ for the catalytic ethanol steam reforming reaction. Catal. Today 2015, 253, 99-105. [CrossRef]

18. Moretti, E.; Storaro, L.; Talon, A.; Chitsazan, S.; Garbarino, G.; Busca, G.; Finocchio, E. Ceria-zirconia based catalysts for ethanol steam reforming. Fuel 2015, 153, 166-175. [CrossRef]

19. Zhou, G.; Shah, P.R.; Montini, T.; Fornasiero, P.; Gorte, R.J. Oxidation enthalpies for reduction of ceria surfaces. Surf. Sci. 2007, 601, 2512-2519. [CrossRef]

20. He, B.J.-J.; Wang, C.-X.; Zheng, T.-T.; Zhao, Y.-K. Thermally induced deactivation and the corresponding strategies for improving durability in automotive three-way catalysts. Johnson Matthey Technol. Rev. 2016, 60, 196-203. [CrossRef] 
21. Cargnello, M.; Doan-Nguyen, V.V.; Gordon, T.R.; Diaz, R.E.; Stach, E.A.; Gorte, R.J.; Fornasiero, P.; Murray, C.B. Control of metal nanocrystal size reveals metal-support interface role for ceria catalysts. Science 2013, 341, 771-773. [CrossRef] [PubMed]

22. Onn, T.M.; Zhang, S.; Arroyo-Ramirez, L.; Xia, Y.; Wang, C.; Pan, X.; Graham, G.W.; Gorte, R.J. High-surface-area ceria prepared by ALD on $\mathrm{Al}_{2} \mathrm{O}_{3}$ support. Appl. Catal. B 2017, 201, 430-437. [CrossRef]

23. Onn, T.M.; Dai, S.; Chen, J.; Pan, X.; Graham, G.W.; Gorte, R.J. High-surface area ceria-zirconia films prepared by atomic layer deposition. Catal. Lett. 2017, 147, 1464-1470. [CrossRef]

24. Singh, J.A.; Yang, N.; Bent, S.F. Nanoengineering heterogeneous catalysts by atomic layer deposition. Annu. Rev. Chem. Biomol. Eng. 2017, 8, 41-62. [CrossRef] [PubMed]

25. Miikkulainen, V.; Leskelä, M.; Ritala, M.; Puurunen, R.L. Crystallinity of inorganic films grown by atomic layer deposition: Overview and general trends. J. Appl. Phys. 2013, 113, 2. [CrossRef]

26. Bonk, A.; Remhof, A.; Maier, A.C.; Trottmann, M.; Schlupp, M.V.F.; Battaglia, C.; Vogt, U.F. Low-Temperature Reducibility of $\mathrm{M}_{x} \mathrm{Ce}_{1-x} \mathrm{O}_{2}(\mathrm{M}=\mathrm{Zr}$, Hf) under Hydrogen Atmosphere. J. Phys. Chem. C 2016, 120, 118-125. [CrossRef]

27. Zhou, G.; Shah, P.R.; Kim, T.; Fornasiero, P.; Gorte, R.J. Oxidation entropies and enthalpies of ceria-zirconia solid solutions. Catal. Today 2007, 123, 86-93. [CrossRef]

28. Kaspar, J.; Fornasiero, P.; Balducci, G.; Di Monte, R.; Hickey, N.; Sergo, V. Effect of $\mathrm{ZrO}_{2}$ content on textural and structural properties of $\mathrm{CeO}_{2}-\mathrm{ZrO}_{2}$ solid solutions made by citrate complexation route. Inorg. Chim. Acta 2003, 349, 217-226. [CrossRef]

29. Bunluesin, T.; Gorte, R.J.; Graham, G. Co oxidation for the characterization of reducibility in oxygen storage components of three-way automotive catalysts. Appl. Catal. B 1997, 14, 105-115. [CrossRef]

30. Kim, T.; Vohs, J.M.; Gorte, R.J. Thermodynamic investigation of the redox properties of ceria-zirconia solid solutions. Ind. Eng. Chem. Res. 2006, 45, 5561-5565. [CrossRef]

31. Shah, P.R.; Kim, T.; Zhou, G.; Fornasiero, P.; Gorte, R.J. Evidence for entropy effects in the reduction of ceria-zirconia solutions. Chem. Mater. 2006, 18, 5363-5369. [CrossRef]

32. Anthony, S.Y.; Küngas, R.; Vohs, J.M.; Gorte, R.J. Modification of SOFC cathodes by atomic layer deposition. J. Electrochem. Soc. 2013, 160, F1225-F1231.

33. Jia, L.; Farouha, A.; Pinard, L.; Hedan, S.; Comparot, J.-D.; Dufour, A.; Tayeb, K.B.; Vezin, H.; Batiot-Dupeyrat, C. New routes for complete regeneration of coked zeolite. Appl. Catal. B 2017, 219, 82-91. [CrossRef]

34. Lv, Q.; Zhang, S.; Deng, S.; Xu, Y.; Li, G.; Li, Q.; Jin, Y. Transparent and water repellent ceria film grown by atomic layer deposition. Surf. Coat. Technol. 2017, 320, 190-195. [CrossRef] 